Article

\title{
Using Life Cycle Assessment to Inform Decision-Making for Sustainable Buildings
}

\author{
Mieke Vandenbroucke ${ }^{1, *}$, Waldo Galle ${ }^{1}$, Niels De Temmerman ${ }^{1}$, Wim Debacker ${ }^{2}$ and \\ Anne Paduart 1
}

1 TRANSFORM Research Team, Department of Architectural Engineering, Vrije Universiteit Brussel, Pleinlaan 2, 1050 Brussels, Belgium; E-Mails: waldo.galle@vub.ac.be (W.G.); niels.de.temmerman@vub.ac.be (N.T.); anne.paduart@vub.ac.be (A.P.)

2 Unit Smart Energy and Built Environment, VITO NV, Boeretang 200, 2400 Mol, Belgium; E-Mail: wim.debacker@vito.be

* Author to whom correspondence should be addressed; E-Mail: mieke.vandenbroucke@vub.ac.be; Tel.: +32-2-6291-364.

Academic Editors: Chimay J. Anumba and Elma Durmisevic

Received: 28 February 2015 / Accepted: 13 May 2015 / Published: 21 May 2015

\begin{abstract}
Because the student residences of the Vrije Universiteit Brussel built in 1973 are not adapted to current comfort standards, the university decided to construct new accommodation facilities at the border of the campus. However, besides demolition, there was no strategy on how to deal with the existing ones. In the search for a more sustainable strategy, the university's administration assigned the TRANSFORM research team to define various design strategies and to assess the long-term environmental consequences in order to select the best strategy by the use of Life Cycle Environmental Assessment. Current Life Cycle Environmental Assessments generally include maintenance, repair, replacement and operational energy consumption during use, but do not include future refurbishments. However, it is likely that their impact cannot be neglected either. Therefore, this article offers a framework which takes future refurbishments into account, in addition to the standard use impacts: initial and end-of-life impact. We report on the construction assemblies, the results of the assessments conducted and the advice provided. The results confirm that the impact of future refurbishments cannot be neglected. In addition, we observed that there were significant environmental savings when transforming the residences compared to new construction, and long-term benefits of a design enabling the reuse of building elements.
\end{abstract}


Keywords: life cycle design; Life Cycle Environmental Assessment; refurbishment; case study; design for change

\section{Introduction}

\subsection{Context Research}

To limit the environmental impact of the construction sector, regulations in Europe nowadays mainly emphasise increased performance of the insulation layer for reducing the operational energy consumption of a building. By taking only the energy consumption into account, the environmental impact of the other life stages is neglected. However, increasing the thickness of the insulation layer increases the impact of the production of those insulation materials too, and the relative impacts of the other life stages gain significance with respect to the whole life cycle [1]. Studies show that the significance of materials increases as the insulation layer performs better; the environmental impact of the used materials can neutralise the energy gain or even increase the total impact $[2,3]$. Moreover, potential future refurbishments cause an additional increase in environmental impact. Because those future refurbishments are not taken into account in a conventional design, this impact cannot be neglected either [4]. Therefore, a design that anticipates the whole life cycle of a building and takes into account material consumption is a better way to decrease the environmental impact of a building.

\subsection{State-of-the-Art}

Life Cycle Assessment (LCA) is a suitable method for exploring environmental impacts. The environmental impacts are linked to relevant inputs and outputs of the product system, such as raw materials, energy and water use, emissions to air, land and water, waste, co-products and other releases [5]. Traditionally, LCA examines the environmental impact of a product or process over its entire life cycle, including raw material extraction, manufacturing, use and end-of-life disposal [6]. Today, more and more LCA studies evaluate large systems too, such as buildings as a whole [7-9], or even neighbourhoods [10]. Many of those LCA-studies solely focus on energy [11], which is called Life Cycle Energy Analysis (LCEA). It considers all energy inputs during the life cycle of a building [12]. It includes embodied, operational and demolition energy. Some studies, such as [2,13] and [10] consider user transport energy demand too.

The impact of future refurbishments has been left out in most LCEA and LCA studies. However, the impact of future refurbishments cannot be neglected either [4]. It is implausible that for example the space plan will not change during its lifespan, especially if the function is commercial or public. Some studies use LCA as a decision-making tool to analyse the impact of typology [10], thermal performance [7,14], energy supply systems [9] or heating systems [15-17]. A limited number of studies use LCA as a decision-making tool to optimise construction assemblies. Some studies [2,9,18,19] compare structural or insulation materials to validate their general findings. Paduart evaluated materials of more functional layers, such as the finishing layer, to inform people about their influence on the overall environmental impact of a construction assembly [4]. 
Therefore, in this study we will include future refurbishments to search for a more sustainable strategy than the demolition of 352 obsolete student residences. In addition, we will compare building materials of several functional layers. An earlier study highlighted the possible environmental benefits of reusing existing buildings [1]. The material emissions for the refurbished building were less than a quarter of those from conventionally constructed newly built homes with similar energy efficiency. By reusing existing buildings, significant initial savings can be obtained by reducing the need for new construction materials and decreasing the impact of the building process.

In order to obtain a lower environmental impact compared to conventional new construction, the influence of an alternative construction method will be analysed. This construction method is based on the design approach "Re-Design for Change" [4]. This design approach implements the time dimension during the design phase by applying key concepts such as "Design for Disassembly". The purpose is to make a building easily adaptable during its lifetime in order to meet the changing requirements of society and users, such as changing standards, family composition, changing patterns of life and an evolving work environment.

\subsection{Aims of this Study}

With this case study we want to explore the possibilities of Life Cycle Assessments (LCA) when designing buildings. Therefore, this paper illustrates how environmental life cycle assessments can help designers to design a sustainable transformation. Different transformation strategies are defined and evaluated with the aid of life cycle environmental assessments. After those evaluations we should be able to give objective advice leading to a sustainable solution. To achieve the goals of this research, several research questions have to be answered:

- Is it useful to consider future refurbishments?

- What is the influence of new construction on the outcomes compared to transformation?

- What is the influence of a demountable detailing on the outcomes compared to conventional detailing?

\section{Methodology}

\subsection{Case Study}

The particular case discussed in this paper considers the assembly of 352 student residences located in the green heart of Etterbeek campus of the Vrije Universiteit Brussel (Figure 1). Although constructed for temporary housing purposes in 1973, additional housing units have been built in 1978 and are still in use today. However, they are outdated and no longer comply with contemporary regulations [20].

With the intent to tackle the university's expansion, a large construction project has been planned on the campus. Among other things, this project includes the establishment of new research, education and housing facilities. Consequently, the 352 existing residences have become obsolete and are threatened by demolition. However, two arguments force us to think about alternative strategies for dealing with the existing student residences. 
First, the residences have a specific historical value. Not only do they epitomise the turbulent foundation process of the Vrije Universiteit Brussel in the early seventies, they are also an application by the Belgian modernist architect Willy Van Der Meeren of the Swiss construction system Variel. Van Der Meeren adopted this modular construction system because the booming standardisation and prefabrication methods of the time allowed him to quickly install a large assembly of residences. Still in use today, the residences have become a renowned example of the flexible and industrialised architecture that flourished worldwide during the seventies.
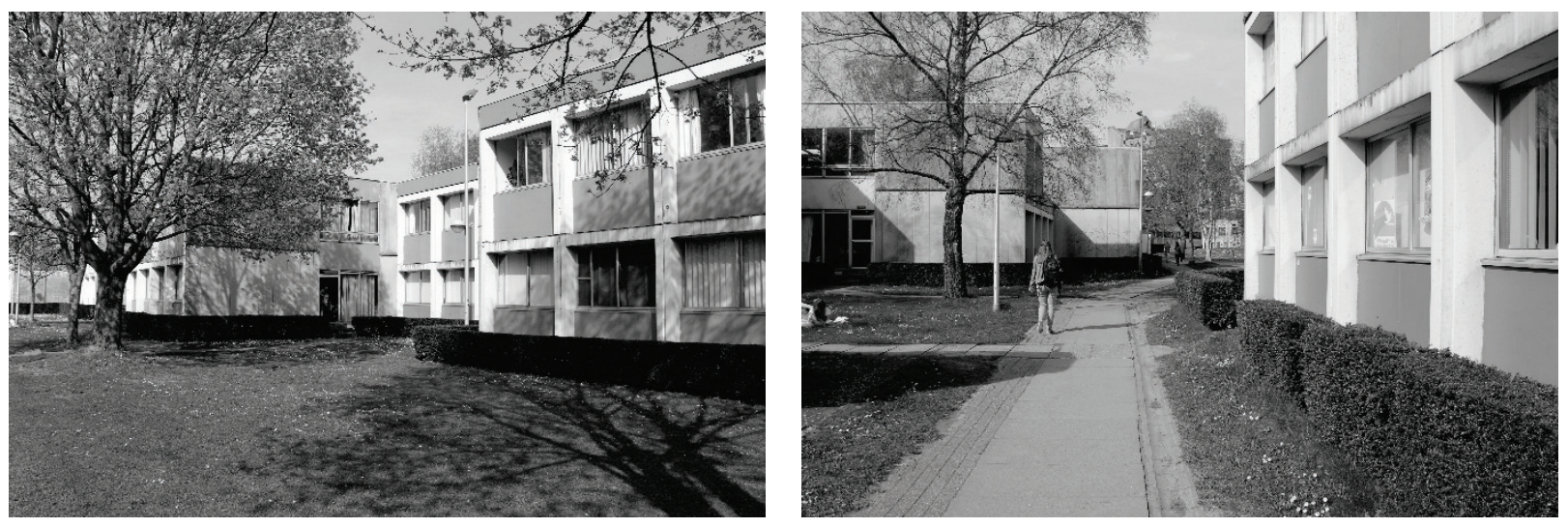

Figure 1. The student residences, characteristic of far-reaching industrialisation, have become obsolete after more than 40 years. However, their concrete frames can still be reused. (Pictures by the authors).

Moreover, Van der Meeren did not apply this construction system uncritically. Carefully shifting and stacking the individual concrete modules of the system, he created a village-like assembly. Characterised by large public squares and smaller private terraces, the assembly still suits the various needs of the students living on the university campus [21].

Second, from a preliminary inspection of the construction it could be concluded that the load bearing frames can be reused. Based on technical studies and visual inspection, each type of building element was assessed. Infill and finishing elements such as roofs, ceilings, façades, walls, floors and exterior joinery have reached their end-of-life. They show wear and tear due to normal usage and weather exposure, but also because of inadequate insulation and ventilation. Additionally, some contain asbestos.

Also, the load bearing concrete frames are damaged. Small cracks and grooves are seen in the upper part of the porches and concrete is dislodged at some corners. Nevertheless, the structure as a whole is stable and in good condition. Moreover, because the frames have been designed to support up to three storeys [22] it is assumed that the frames can be completely reused after the indispensable reparations. These findings have yet to be confirmed by in situ tests and further (laboratory) research.

For those two reasons, it is necessary to define alternative strategies to the demolition of the student residences (Figure 2). A transformation related to a new function is therefore formulated as the alternative option to be assessed. The way the concrete frames will be insulated will strongly affect their industrialised look. For that reason two strategies are further considered. First, a reconversion insulated from the inside is considered. The new façade is placed within the frames, just like the current situation, thereby leaving them visible from the outside. Second, a reconversion insulated from the outside 
is considered. This way the frames are wrapped up and protected against the outdoor climate. The demolition of the frames and the new construction of an equivalent functional space are selected as the benchmarks in our assessment.

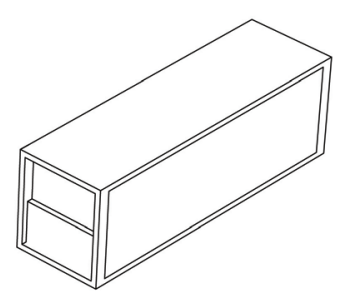

(a)

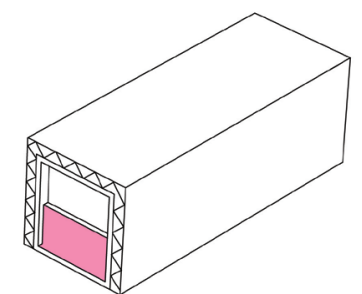

(b)

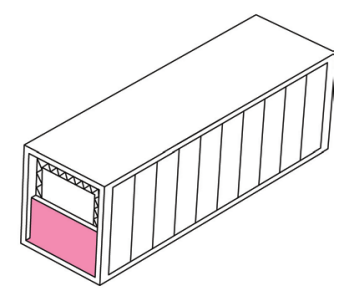

(c)

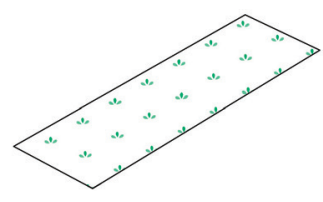

(d)

Figure 2. In search for a sustainable strategy to deal with the existing student residences, two alternative transformations will be assessed and compared with two benchmarks: New construction and total demolition. (a) New construction; (b) Transformation Insulated externally; (c) Transformation Insulated internally; (d) Demolition.

\subsection{Elaboration of Design Strategies}

In cooperation with the VUB "Task Group XY" several possible reconversions were selected. For each function the main physical construction and safety regulations are retrieved. Subsequently, building elements are detailed fulfilling all requirements. For each building element - a floor at ground level, a suspended floor, a flat roof, an external wall, the external joinery and an internal and partition wall - a plausible detailing is elaborated according to different transformation strategies. For each element a conventional and a demountable detailing is developed too.

Then, the developed building elements were used to predesign a reconversion of some of the modules to a student information hub. With the aid of a Building Information Model (BIM), which is a digital representation of physical and functional characteristics of a building, we calculated how much material is needed to renovate these modules according to contemporary standards and requirements.

\subsection{Evaluation of Design Strategies}

To understand the environmental consequences in the long term, the different strategies were evaluated. A sustainable approach evidently includes more than merely the initial environmental impact and takes the future into account too. A LCA is therefore the basic method to evaluate the proposed strategies. International standards describe the methodology in greater detail [23,24].

\subsubsection{System Boundaries}

This assessment analyses raw material extraction, manufacturing of new needed construction materials, their transport, the building process, use, demolition, transport of waste materials and the end-of-life treatment. In the first step, the assessment includes the stripping of the concrete structure, the waste treatment of all outdated construction materials and the demolition and the waste treatment of the concrete structure in case of a new construction. The evaluation of the building process is limited to material losses due to cutting products to size, while the analysis of the use stage contains 
maintenance, repair, replacement, refurbishment and energy consumption for heating caused by transmission losses. The user transport energy demand was not considered. The impact would be equal for all scenarios and design strategies.

\subsubsection{Functional Unit}

The functional unit is the cluster of characteristics which should be the same when comparing different design options [24], e.g., thermal and acoustic performance. In this research, the construction elements are evaluated for a functional unit of $1 \mathrm{~m}^{2}$ of the concerned element and at building level the compared strategies have an equal net floor surface of $433 \mathrm{~m}^{2}$. We assume a possible maximum remaining lifespan of 79 years, because a concrete structure has a technical lifespan of 120 years or more [25] and the evaluated structure is already 41 years old. To analyse the sensitivity of the results, a lifespan of 30 years as a minimum and 60 years as average will be calculated.

\subsubsection{Environmental Impact Assessment}

During the life cycle inventory (LCI) analysis, information is collected on material and energy flows of all considered life cycle stages. The environmental impacts of production of the various construction materials (Table 1) are identified using a Swiss database called ecoinvent, version 3.1 [26], which was adapted to the Belgian market. For unknown values, realistic estimates are assumed based on Environmental Product Declarations (EPD) or literature. The data on average transport distances and vehicles used for transport of the construction materials to the construction site is based on surveys [27]. The impact of the building process is limited to material losses due to cutting products to size during the building process and has been attributed an average percentage of $5 \%$, as the other processes and emissions that take place during the building process are negligible compared to other life stages [28].

The analysis of the use stage contains maintenance, repair, replacement and energy consumption. The frequency of maintenance, repair and replacement of the construction components is based on literature $[25,29]$. The impact of maintenance and repair of the finishing layers have been taken into account by an average percentage of respectively $1 \%$ and $5 \%$ material losses. In addition, maintenance includes cleaning of finishing layers. At the element level, only the energy consumption related to transmission losses can be considered and it is determined using the equivalent degree-day method. A well-insulated dwelling with an average indoor temperature of $18{ }^{\circ} \mathrm{C}$ has approximately 1200 equivalent degree-days [30]. The heat is generated by a condensing natural gas boiler with a variable control of the water temperature, which has a production efficiency of $89 \%$.

The primary energy consumption is calculated with the following formulas:

$$
\begin{gathered}
\text { Primary energy consumption }[\mathrm{kWh}]=Q_{\text {heat }, \text { final }} \cdot f=\frac{Q_{\text {heat, gross }}}{\eta_{\text {production }}} \cdot 1.1=\frac{Q_{\text {heat }, \text { net }}}{\eta_{\text {system }}} \cdot \frac{1.1}{0.89}= \\
\quad \frac{Q_{\text {loss }}-\eta \cdot Q_{\text {gain }}}{0.92} \cdot \frac{1.1}{0.89}=\frac{Q_{\text {loss }}}{0.92} \cdot \frac{1.1}{0.89}=\frac{\left(H_{t}+H_{v}\right) \cdot\left(18-\theta_{e}\right) \cdot t}{0.92} \cdot \frac{1.1}{0.89}=\frac{H_{t} \cdot 1200 \cdot 24}{0.92} \cdot \frac{1.1}{0.89}= \\
\frac{\left(\sum_{i=1}^{n} U_{i} \cdot A_{i}+\sum_{k=1}^{m} l_{k} \cdot \Psi_{k}+\sum_{i=1}^{n} A_{i} \cdot U_{\text {eq }, i}\right) \cdot 1200 \cdot 24}{0.92 \cdot 1000} \cdot \frac{1.1}{0.89}=\frac{U_{i} \cdot 1 \cdot 1200 \cdot 24}{0.92 \cdot 1000} \cdot \frac{1.1}{0.89}=U_{i} \cdot 38.7
\end{gathered}
$$

with $Q_{\text {heat,final }}$ as final energy demand for space heating, $f$ as primary energy conversion factor (= 1.1 for gas), $Q_{\text {heat,gross }}$ as gross energy demand for space heating, $\eta_{\text {production }}$ as production efficiency ( $=0.89$ for a condensing natural gas boiler), $Q_{\text {heat }, \text { net }}$ as net energy demand for space 
heating, $\eta_{\text {system }}$ as system efficiency $(=0.92$ for radiators with thermostats and with a variable control of the water temperature), $Q_{\text {loss }}$ as heat losses, $\eta \cdot Q_{\text {gain }}$ as solar and internal gains (n/a), $H_{t}$ as transmission losses, $H_{v}$ as ventilation losses (n/a), $\theta_{e}$ as outside temperature, $t$ as time period, $\sum_{i=1}^{n} U_{i}$. $A_{i}$ as 1 D-transmission, $\sum_{k=1}^{m} l_{k} \cdot \Psi_{k}$ as thermal bridges (n/a), $\sum_{i=1}^{n} A_{i} \cdot U_{e q, i}$ as contact ground (n/a), $U_{i}=U$-value, $A_{i}=$ transmission area $\left(=1 \mathrm{~m}^{2}\right)$.

Subsequently, with the aid of the ecoinvent database, the primary energy consumption is converted to environmental impacts.

Table 1. Most building materials are retrieved from the ecoinvent database; others are based on EPD's or literature. The following table shows background information on the main buildings materials of construction assemblies insulated externally.

\begin{tabular}{|c|c|c|c|}
\hline Building element & Material & Material from Ecoinvent Database & Amount \\
\hline \multirow{4}{*}{ Roof Conventional } & Bitumen & Bitumen seal & $4 \mathrm{~kg} / \mathrm{m}^{2}$ \\
\hline & PUR & Polyurethane, rigid foam & $10 \mathrm{~kg} / \mathrm{m}^{2}$ \\
\hline & Wooden battens & Sawn wood, softwood, kiln, dried, planed & $0.004 \mathrm{~m}^{3} / \mathrm{m}^{2}$ \\
\hline & Gypsum board & Gypsum plasterboard & $23 \mathrm{~kg} / \mathrm{m}^{2}$ \\
\hline \multirow{5}{*}{ Roof Alternative } & Gravel & Gravel, crushed & $85 \mathrm{~kg} / \mathrm{m}^{2}$ \\
\hline & EPDM & $\mathrm{n} / \mathrm{a}$, based on [29] & $1 \mathrm{~kg} / \mathrm{m}^{2}$ \\
\hline & PUR & Polyurethane, rigid foam & $10 \mathrm{~kg} / \mathrm{m}^{2}$ \\
\hline & Wooden battens & Sawn wood, softwood, kiln, dried, planed & $0.004 \mathrm{~m}^{3} / \mathrm{m}^{2}$ \\
\hline & Plywood & Plywood, for indoor use & $0.015 \mathrm{~m}^{3} / \mathrm{m}^{2}$ \\
\hline \multirow{6}{*}{ External wall Conventional } & Paint, interior & Alkyd paint, without water & $1 \mathrm{~kg} / \mathrm{m}^{2}$ \\
\hline & Plaster, interior & Cover plaster, mineral & $20 \mathrm{~kg} / \mathrm{m}^{2}$ \\
\hline & Sand-lime brick & Sand-lime brick & $200 \mathrm{~kg} / \mathrm{m}^{2}$ \\
\hline & EPS & Polystyrene, expandable & $6 \mathrm{~kg} / \mathrm{m}^{2}$ \\
\hline & Plaster, exterior & Cover plaster, mineral & $20 \mathrm{~kg} / \mathrm{m}^{2}$ \\
\hline & Paint, exterior & Alkyd paint, without water & $1 \mathrm{~kg} / \mathrm{m}^{2}$ \\
\hline \multirow{7}{*}{ External wall Alternative } & Plywood & Plywood, for indoor use & $0.075 \mathrm{~m}^{3} / \mathrm{m}^{2}$ \\
\hline & OSB & Oriented strand board & $0.015 \mathrm{~m}^{3} / \mathrm{m}^{2}$ \\
\hline & Timber I-joists & Mix of sawn wood and fibreboard & $0.01 \mathrm{~m}^{3} / \mathrm{m}^{2}$ \\
\hline & Mineral wool & Rock wool & $5 \mathrm{~kg} / \mathrm{m}^{2}$ \\
\hline & Wood fibre board & Fibreboard, hard & $0.02 \mathrm{~m}^{3} / \mathrm{m}^{2}$ \\
\hline & Wooden studs and battens & Sawn wood, softwood, kiln, dried, planed & $0.008 \mathrm{~m}^{3} / \mathrm{m}^{2}$ \\
\hline & Cement fibre board & Fibre cement facing tile & $19 \mathrm{~kg} / \mathrm{m}^{2}$ \\
\hline
\end{tabular}

Future expenses and savings are reduced to their present value by discounting them. This way our results are corrected for risk aversion and the endowment effect so that impacts at different moments in the future can be compared objectively. Therefore, a discount rate of $3 \%$ and an inflation rate of $2 \%$ are applied [30].

A fixed impact per kilogram demolished construction material is assumed. In reality, the impact will depend on the composition of the components and the way components are connected. Because the LCI data in ecoinvent v.3.1 is limited an abstraction is assumed. Finally, the end-of-life treatment of the construction materials is mainly based on surveys [27]. All impacts till the sorting facility are taken into account; all other impacts, such as transport to the recycling facility and the recycling 
process, are allocated to the next system [24,31]. Benefits of energy recovery, recycling and reuse of the construction waste are thus not included in this study.

\subsubsection{Interpretation}

The "Environmental Performance of Materials used in Building Elements" determination method (MMG-method) was used to interpret the results [27]. This Belgian evaluation methodology converts the impact of various environmental indicators into monetary values, thereby allowing the comparison of building elements based on a single unit $\left(€ / \mathrm{m}^{2}\right)$. The method includes midpoint and endpoint indicators. A midpoint indicator is an indicator between emission and endpoint in the environmental mechanism [32]. The midpoint is usually chosen when further modelling is not feasible or involves uncertainties that are too large [33]. Their drawback is the supposed lower relevance for decision-making. Hence, the purpose of endpoint indicators is the representation of the ultimate contributions to humans and ecosystems, but with the drawback of having a higher level of uncertainty [32]. Lenzen indicated that probabilities of mistakenly favouring one comparable alternative over another can be as high as $80 \%$ [34].

Therefore, the authors of the method have opted only for an "endpoint method" where recommended by the ILCD Handbook [35]. The indicators were selected from the ReCiPe impact assessment method, which offers a reliable assessment of environmental impacts [36]. In this method, the characterisation value of each individual environmental indicator-such as global warming potential and ozone depletion-is multiplied by a factor (e.g., $X \mathrm{~kg} \mathrm{CO} 2$ equivalents times $Y € / \mathrm{kg} \mathrm{CO}_{2}$ equivalents) (Table 2). Those factors express the proportion of the damage to the environment and/or humans that is passed on to society, such as loss of biodiversity. Each factor is based on a financial amount that would be given to avoid damage or to eliminate any existing damage.

Table 2. The characterisation value of each environmental indicator of a selected impact method is multiplied by a factor, based on [27], in order to allow the comparison of building elements.

\begin{tabular}{|c|c|c|c|}
\hline Environmental Indicator & Unit & Factor & Impact Method \\
\hline Global warming potential & $\mathrm{kg} \mathrm{CO} 2$ eqv. & 0.06 & ReCiPe midpoint \\
\hline Ozone depletion & $\mathrm{kg} \mathrm{CFC} \mathrm{Cl}_{11}$ eqv. & 49.1 & ReCiPe midpoint \\
\hline Terrestrial acidification & $\mathrm{kg} \mathrm{SO}_{2}$ eqv. & 0.85 & ReCiPe midpoint \\
\hline Eutrophication, freshwater & $\mathrm{kg} P$ eqv. & 100 & ReCiPe midpoint \\
\hline Eutrophication, marine & $\operatorname{kg~N}$ eqv. & 18 & ReCiPe midpoint \\
\hline Photochemical oxidant formation & kg NMVOC eqv. & 7.4 & ReCiPe midpoint \\
\hline Depletion of non-fossil resources & $\mathrm{kg} \mathrm{Fe} \mathrm{eqv.}$ & 0.052 & ReCiPe midpoint \\
\hline Human toxicity & DALY & 60000 & ReCiPe endpoint \\
\hline Particulate matter formation & DALY & 60000 & ReCiPe endpoint \\
\hline Ionising radiation & DALY & 60000 & ReCiPe endpoint \\
\hline Ecotoxicity, terrestrial & $\mathrm{kg} 1.4 \mathrm{DB}$ eqv. & 4.31 & ReCiPe midpoint \\
\hline Ecotoxicity, freshwater & $\mathrm{kg} 1.4 \mathrm{DB}$ eqv. & 0.0190 & ReCiPe midpoint \\
\hline Ecotoxicity, marine & $\mathrm{kg} 1.4 \mathrm{DB}$ eqv. & 0.0000014 & ReCiPe midpoint \\
\hline Land occupation, urban & $\mathrm{m}^{2} \mathrm{a}$ & 0.036 & ReCiPe midpoint \\
\hline Land occupation, forest & $\mathrm{m}^{2} \mathrm{a}$ & 0.181 & ReCiPe midpoint \\
\hline Land transformation, tropical rain forest & $\mathrm{m}^{2}$ & 0.8 & ReCiPe midpoint \\
\hline
\end{tabular}




\subsection{Requirements}

Possible interesting reconversions were selected in dialogue with the VUB "Task Group XY", such as food, drink or student facilities, an open event hall, a bank, an information hub, shops and a bike repair workshop. Of course, all these functions must comply with several regulations. Table 3 offers a summary of the main requirements and recommendations for each element.

First, in the Brussels-Capital Region there are regulations for new constructions and refurbishments with respect to the thermal insulation [37]. Since the building envelope of the student residences is no longer efficient, more than $75 \%$ of the facade must be rebuilt. As a consequence, the refurbished modules must be seen as "new similar units", making the regulations more severe.

As previously mentioned, the wall panels of the modules contain asbestos. The Brussels-Capital Region imposes that asbestos-containing materials may not be damaged and they may not be modified and cleaned under high pressure [38]. Considering the current local damage to the panels, their removal seems unavoidable in all strategies.

Although the Royal Decree concerning fire prevention [39] is only valid for new constructions and not for transformations, we examined the main requirements in terms of fire safety for the possible future uses. This is because when granting a building permission, construction measures can be demanded that provide an increased fire resistance. Since a possible transformation will be very extensive and the studied functions are mainly publicly accessible, it was assumed that a reconversion will have to meet the requirements of a new construction.

Finally, to achieve improved user comfort, the use of the noise standard regarding, e.g., offices and restaurants [40] is recommended.

Table 3. To develop different strategies, a summary of the requirements and standards has been made for each element. This guaranties that we will compare equivalent functional units.

\begin{tabular}{|c|c|c|c|c|}
\hline Building element & Thermal Performance & Fire Resistance & $\begin{array}{c}\text { Impact Sound } \\
\text { (D)) }\end{array}$ & $\begin{array}{c}\text { Airborne Sound } \\
\text { (D)) }\end{array}$ \\
\hline Floor at ground level & $\leq 0.30 \mathrm{~W} / \mathrm{m}^{2} \mathrm{~K}$ & 1 & 1 & 1 \\
\hline Floor, suspended & $\leq 1 \mathrm{~W} / \mathrm{m}^{2} \mathrm{~K}$ & $\begin{array}{l}\text { R60 } \\
\text { EI60 }\end{array}$ & $\leq 61 \mathrm{~dB}$ & $\geq 56 \mathrm{~dB}$ \\
\hline Roof, flat & $\leq 0.24 \mathrm{~W} / \mathrm{m}^{2} \mathrm{~K}$ & $\begin{array}{c}\text { R30 } \\
\text { EI30 (public/kitchen *) }\end{array}$ & / & $\geq 43 \mathrm{~dB}$ \\
\hline Wall, external & $\leq 0.24 \mathrm{~W} / \mathrm{m}^{2} \mathrm{~K}$ & $\begin{array}{l}\text { R30 (1 level) } \\
\text { R60 (>1 level) }\end{array}$ & / & $\geq 43 \mathrm{~dB}$ \\
\hline Joinery glazing & $\leq 1.1 \mathrm{~W} / \mathrm{m}^{2} \mathrm{~K}$ & 1 & 1 & $\geq 43 \mathrm{~dB}$ \\
\hline Joinery framework & $\leq 1.8 \mathrm{~W} / \mathrm{m}^{2} \mathrm{~K}$ & 1 & 1 & $\geq 43 \mathrm{~dB}$ \\
\hline Wall partition & $\leq 1 \mathrm{~W} / \mathrm{m}^{2} \mathrm{~K}$ & $\begin{array}{c}\text { EI30 (1 level }) \\
\text { EI60 (>1 level })\end{array}$ & $\leq 61 \mathrm{~dB}$ & $\geq 56 \mathrm{~dB}$ \\
\hline Wall, internal & 1 & EI60 (kitchen) * & 1 & $\geq 48 \mathrm{~dB}$ \\
\hline
\end{tabular}




\subsection{Detailing of the Building Elements}

In this paragraph, the building elements are detailed so that they fulfil all requirements set out in the previous section. Each building element - a floor at ground level, a suspended floor, a flat roof, an external wall, the joinery and an internal and partition wall-is detailed according to the different transformation strategies: transformation with internal insulation, transformation with external insulation and new construction with internal and external insulation. A conventional and an alternative, demountable detailing are elaborated for each element. Figure 3 illustrates some elaborated refurbished elements.

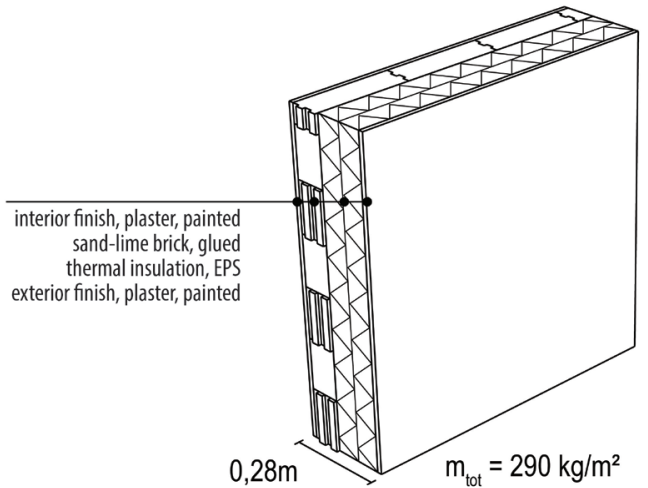

(a)

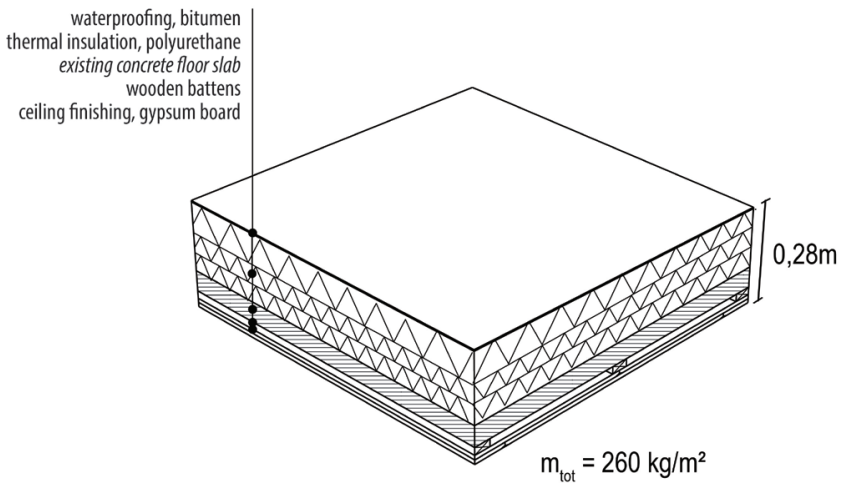

(c)

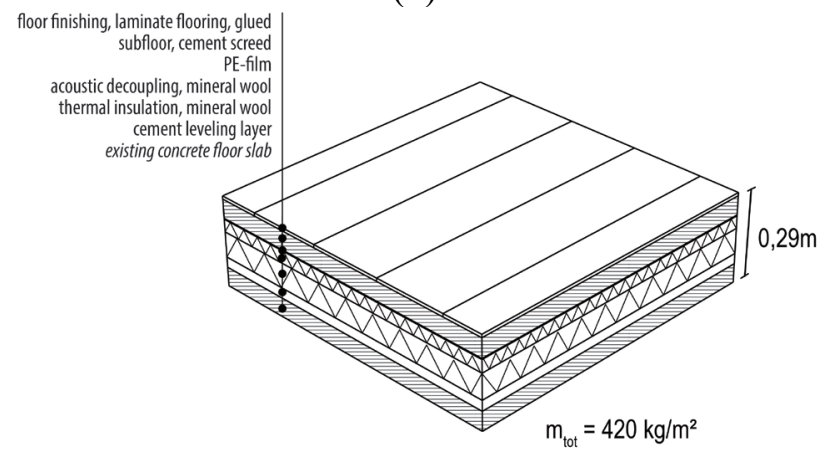

(e)

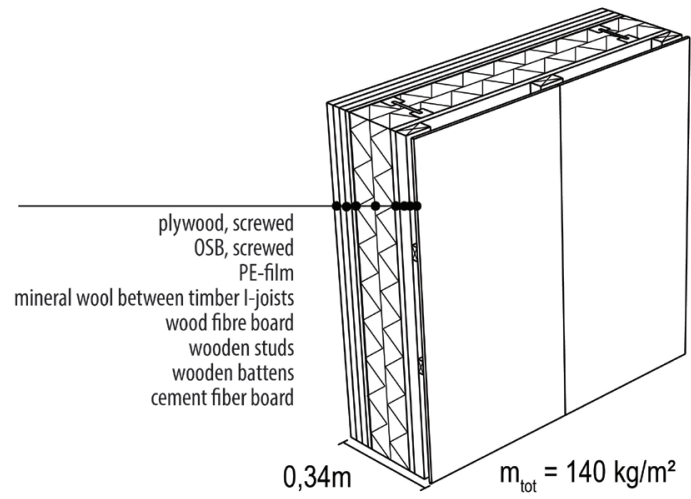

(b)

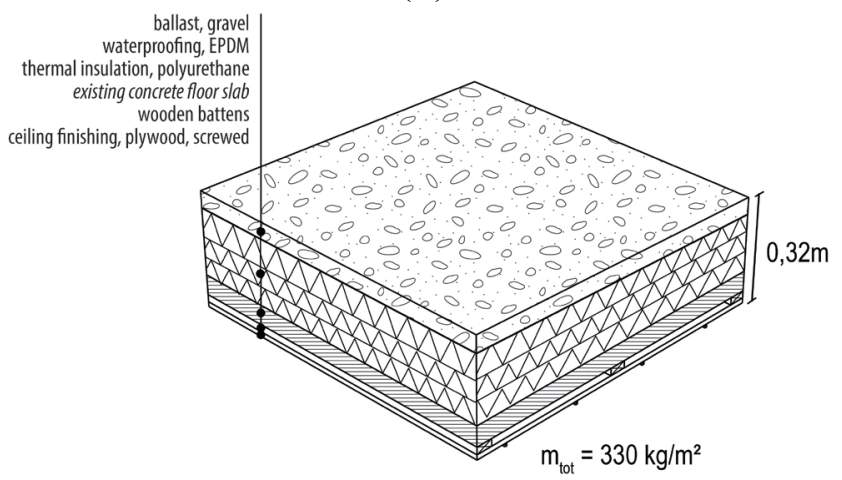

(d)

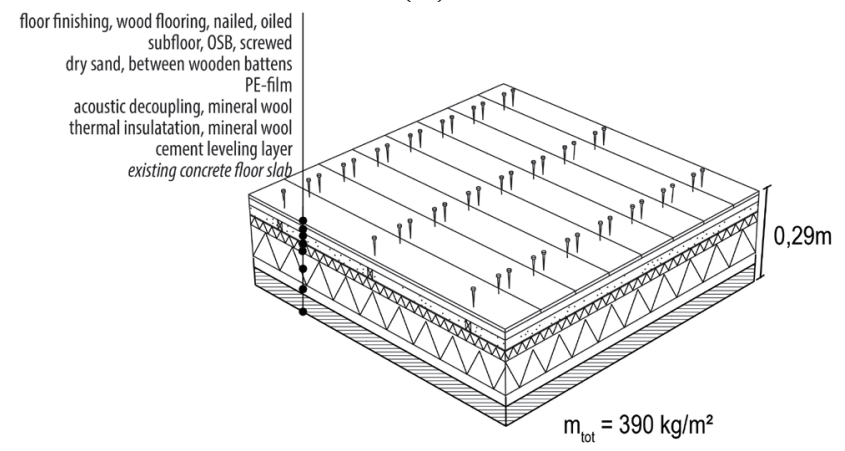

(f)

Figure 3. For each building element and strategy a conventional and demountable detailing has been proposed, e.g., a conventional (a) and demountable (b) external wall, and a conventional (c) and demountable (d) flat roof, all transformed with external insulation; a conventional (e) and demountable (f) ground floor, transformed with internal insulation. 
The positioning of the thermal envelope leads to the main difference between the "transformation insulated internally" and "transformation insulated externally" strategies, either inside the perimeter of the concrete structure or outside. This creates little difference in the detailing of the construction assemblies. However, in case of an external insulation layer, the structure needs additional protection against fire, whereas in the other case the construction assembly makes the structure sufficiently fire resistant. Placing the insulation layer below the existing floor slab seems rather unrealistic for the floor at ground level and is therefore disregarded.

There are more differences between the conventional and the alternative construction assemblies, mainly due to the jointing method. Mortar and glue are primarily used in the conventional proposals and screws in the alternative. Thanks to these dry and reversible connections changes can be made in a simple way without generating additional construction waste. In the life cycle analyses of the next paragraph, reuse of materials that characterise these alternative versions was included as a gain during future adjustments. Commonly used materials were chosen to enable frequent reuse and reversible connections, such as plywood instead of gypsum boards. The alternative versions have a lower weight for most elements since massive components are frequently used in conventional building, whereas lightweight components are used in transformable buildings to make changes easier. This is not valid for the roof, where gravel is used as ballast to keep the waterproofing in place. The alternative elements are generally thicker because more material is needed in order to demonstrate equal characteristics. For example a thick layer of plywood is needed to have an equivalent fire resistance to plaster and sand-lime bricks. When several alternative materials were available, the one with a lower initial environmental impact was chosen, based on NIBE's design guidelines [41].

A newly constructed composition of each building element was developed too, in order to compare the environmental impact of a new construction with a transformation. The main difference in detailing the new built elements is the way the structure is built: no concrete slabs on beams, but beamless floors.

\section{Results}

\subsection{Introduction}

To understand the environmental consequences of all strategies in the long term, the different strategies were evaluated and are described in this paragraph, firstly at the element level and secondly at the building level. The advantage of evaluating at the element level is that the analysis can be conducted in an early stage of the design process. Additionally, less data are needed and high impact from a particular construction material can be easily detected. Assessments at the building level can put the results at the element level in perspective. For each element and strategy, the outcomes are divided into the initial environmental impact (IE) and life cycle environmental impact (LE). The impact of stripping or demolishing the element, the impact of producing and transporting the new building materials and components and the impact of (re)constructing the element are part of the initial impact. The life cycle impact includes the initial impact plus the impact of maintenance, reparations, replacements and energy consumption for heating caused by transmission losses during the entire remaining service life of the structure plus the impact of demolition, waste transport and waste treatment at the end of the service life. In the first scenario (LEmin) it is assumed that no other 
modifications will happen after this one. However, this is implausible given the commercial and public nature of most examined functions. Therefore, we will take future refurbishments into account by assuming the technical services undergo adaptations every 15 years in a second scenario (LEaver), or, even more frequently, every 10 years in a third scenario (LEmax). The same assumptions are used for the internal walls and for the partition walls: changes are assumed every 30 years (LEaver) and 20 years (LEmax). When the technical services have to be refurbished we assume that the finishing layers will have to be demolished (in the case of conventional detailed elements) or deconstructed and rebuilt (in the case of demountable and reusable elements). The environmental impact of these demolition and reconstruction steps of the finishing layers are taken into account. If the construction assembly is detailed reversibly, the components can be reused, although a material loss of $5 \%$ is realistic. The impact of the materials of the technical services is not taken into account, as detailed technical schemes were not available in this stage of the design process. In addition, earlier studies indicated that the contribution of the technical services is minor [17].

\subsection{Evaluation at Element Level}

Figure 4 shows the results of the environmental life cycle assessment of the ground floor. It demonstrates the added value of maintaining the structure, both in the short and long term. In terms of transformation the conventional element scores initially (IE) better than the alternative version. This can partly be explained by the high environmental impact of manufacturing OSB-panels. In the long term (LEmin) it is better to provide an alternative floor assembly, because the floor finishing of the conventional version, e.g., laminate flooring, needs to be replaced more frequently than in the case of wood flooring, which has a high influence on the overall impact of the assembly. As expected, the environmental benefit of using the alternative assembly increases when more refurbishments will take place in the future.

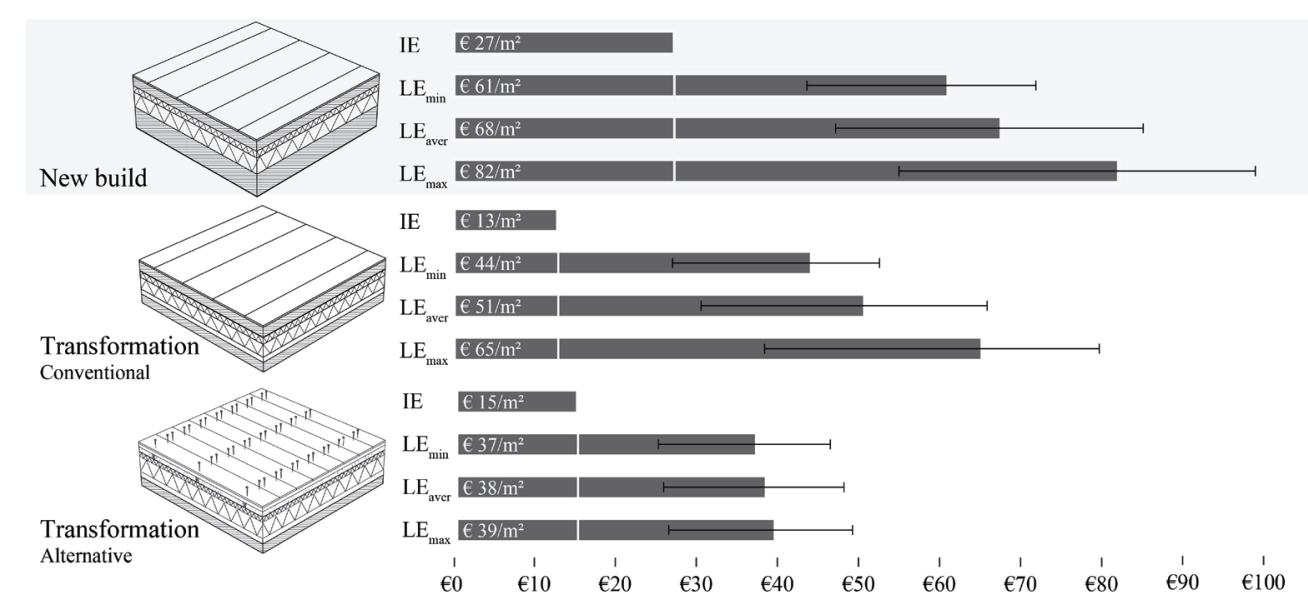

Figure 4. The outcomes of the environmental life cycle assessments of the ground floor show the gains of transforming compared to constructing a new equivalent element, regarding both initial and life cycle environmental impact, with IE as initial environmental impact, $\mathrm{LE}_{\min }$ as life cycle impact with no refurbishments, LEaver as life cycle impact with an average number of refurbishments, $L E_{\max }$ as life cycle impact with a maximum number of refurbishments during 60 years. The error bars represent the results of the sensitivity analysis on a variable lifespan of the building (from 30 to 79 years). 
All inner walls are newly built, because the space plan cannot be reused and will be changed completely. The conventional wall consists of one or two layers of plastered sand-lime brick with mineral wool between both layers in the case of the partition wall. The alternative wall consists of oiled plywood screwed to metal studs with mineral wool between the studs. The partition wall consists of an additional gypsum fibre board layer. The initial impact (IE) of the inner walls is the lowest for the conventional element, due to the low impact of plaster compared to plywood (Figure 5). The conventional assembly - in the long term-scores worse in the case of the internal wall since the different paintjobs has a larger impact than the impact of re-oiling the walls. In both cases, there is a growing environmental benefit of using the alternative assemblies for internal and partition walls when more refurbishments will take place in the future.

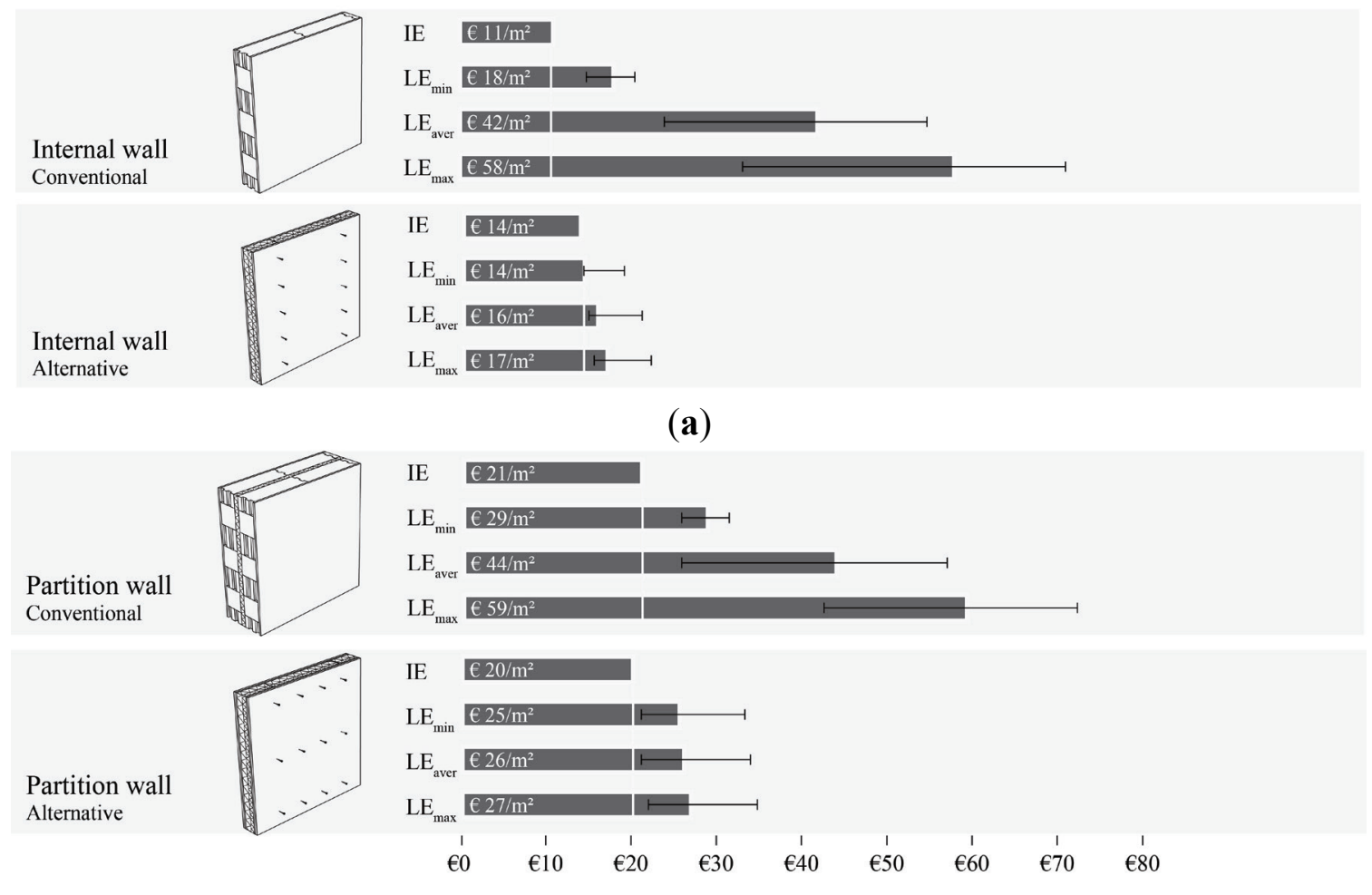

(b)

Figure 5. The outcomes of the life cycle assessment of the (a) internal and (b) partition wall show that the demountable construction assembly has the lowest life cycle environmental impact in those scenarios with average and maximum refurbishment frequencies, with IE as initial environmental impact, LEmin as life cycle impact with no refurbishments, $\mathrm{LE}_{\mathrm{aver}}$ as life cycle impact with an average number of refurbishments, $\mathrm{LE}_{\max }$ as life cycle impact with a maximum number of refurbishments during 60 years. The error bars represent the results of the sensitivity analysis on a variable lifespan of the building (from 30 to 79 years).

Figure 6 illustrates the life cycle assessments of the external wall assemblies insulated internally or externally. The results are similar for both cases. Placing the insulation layer on the inside has a small benefit, since the reused concrete structure does not need an additional protection against fire. A renovated element has a small advantage compared to a new external wall element due to the reuse 
of the structure. The static wall elements have-for all strategies - a lower environmental impact (IE and LE) than the dynamic elements, due to the thick layer of plywood for obtaining an equivalent fire resistance to plaster and sand-lime bricks. Paduart revealed that a dynamic wall can have environmental benefits when a thermal upgrade of the façade is taking place every 15 years [4].

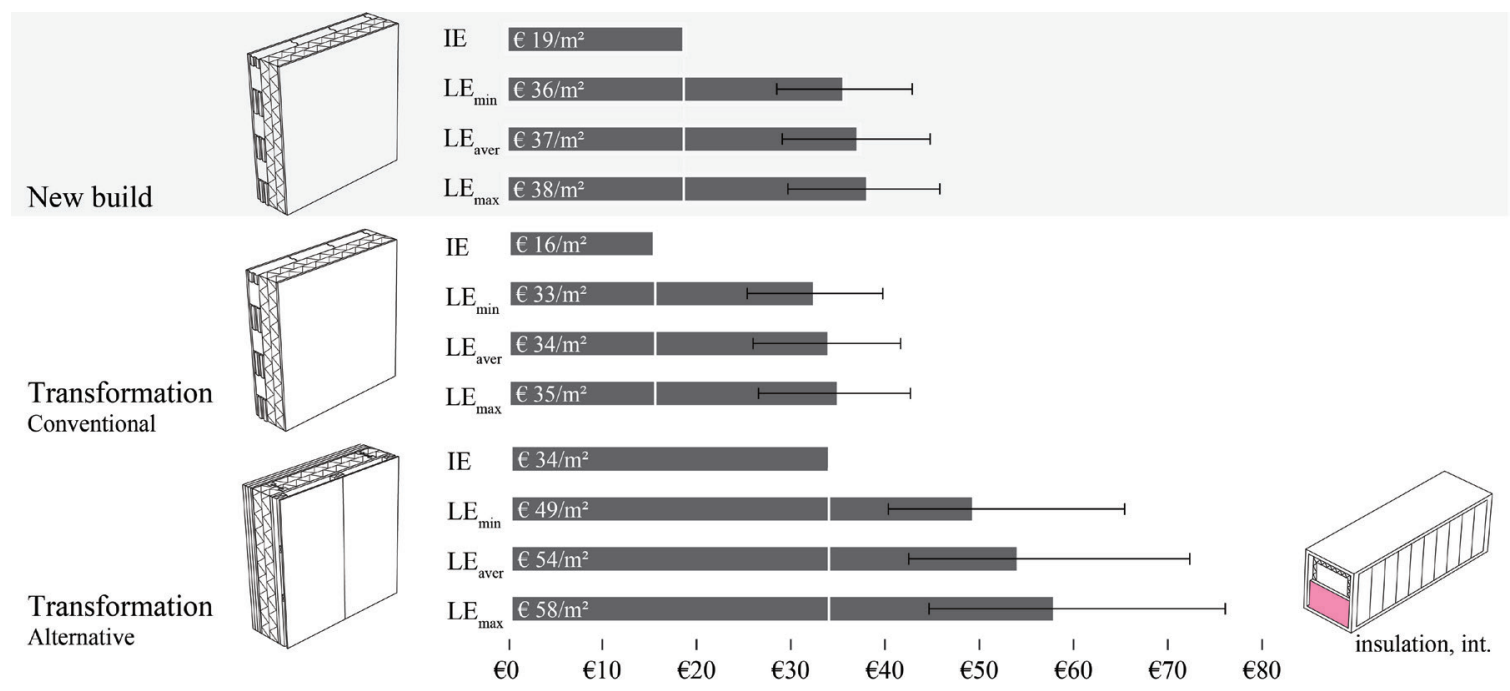

(a)

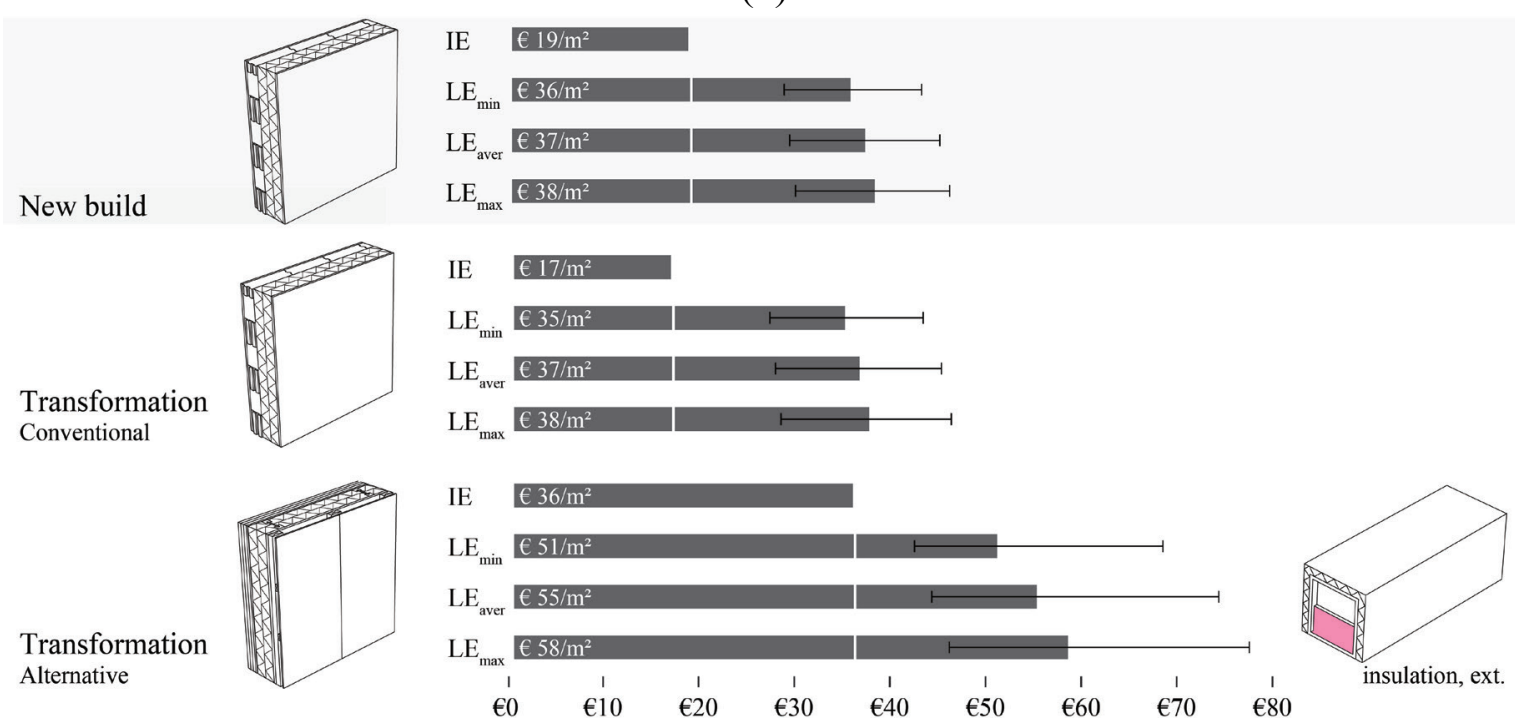

(b)

Figure 6. Based on the outcomes of the life cycle assessments of the external wall, with (a) internal or (b) external wall insulation, the conclusions are similar for both cases: transformation with conventional elements has the lowest impact. With IE as initial environmental impact, LEmin as life cycle impact with no refurbishments, LEaver as life cycle impact with an average number of refurbishments, LEmax as life cycle impact with a maximum number of refurbishments during 60 years, the error bars represent the results of the sensitivity analysis on a variable lifespan of the building (from 30 to 79 years).

Figure 7 shows the results of the evaluation of the roof variants. Again, transformation is better than building a new element thanks to the reuse of the structure. When the insulation layer is located on the inside, the alternative element has a lower impact than the conventional version in the short and long 
term, because mineral wool is used instead of PUR. When more refurbishments are planned in the future the positive difference will further increase. When the insulation layer is placed on the outside of the structure, the initial impact of the conventional version is lower because of the high impact of plywood used instead of gypsum boards. The alternative scores better in the long term, because a paintjob has a larger impact than re-varnishing the plywood. The supplementary wooden framework needed for internal insulation has a higher environmental impact compared to external insulation. However, the alternative version with internal insulation still has a lower impact as mineral wool is used instead of PUR.

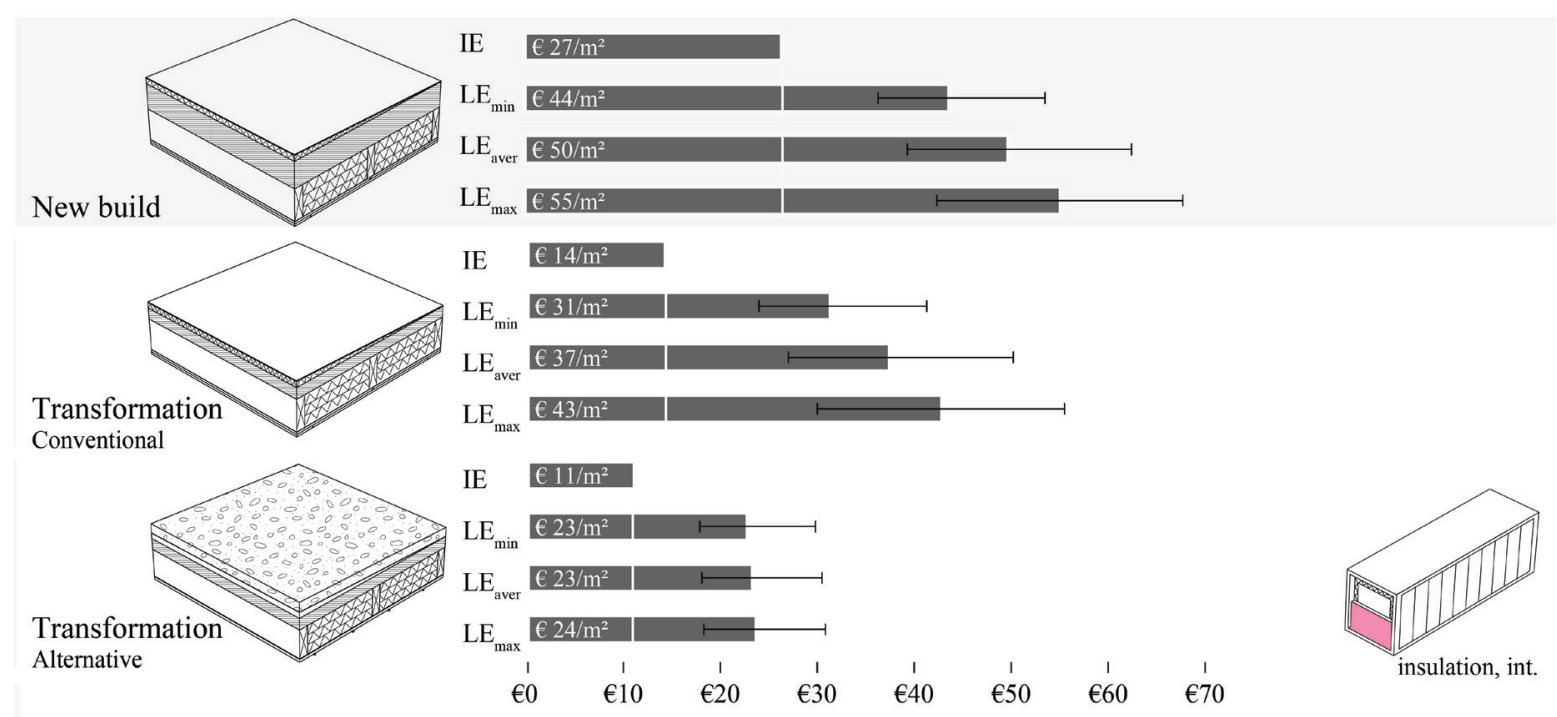

(a)

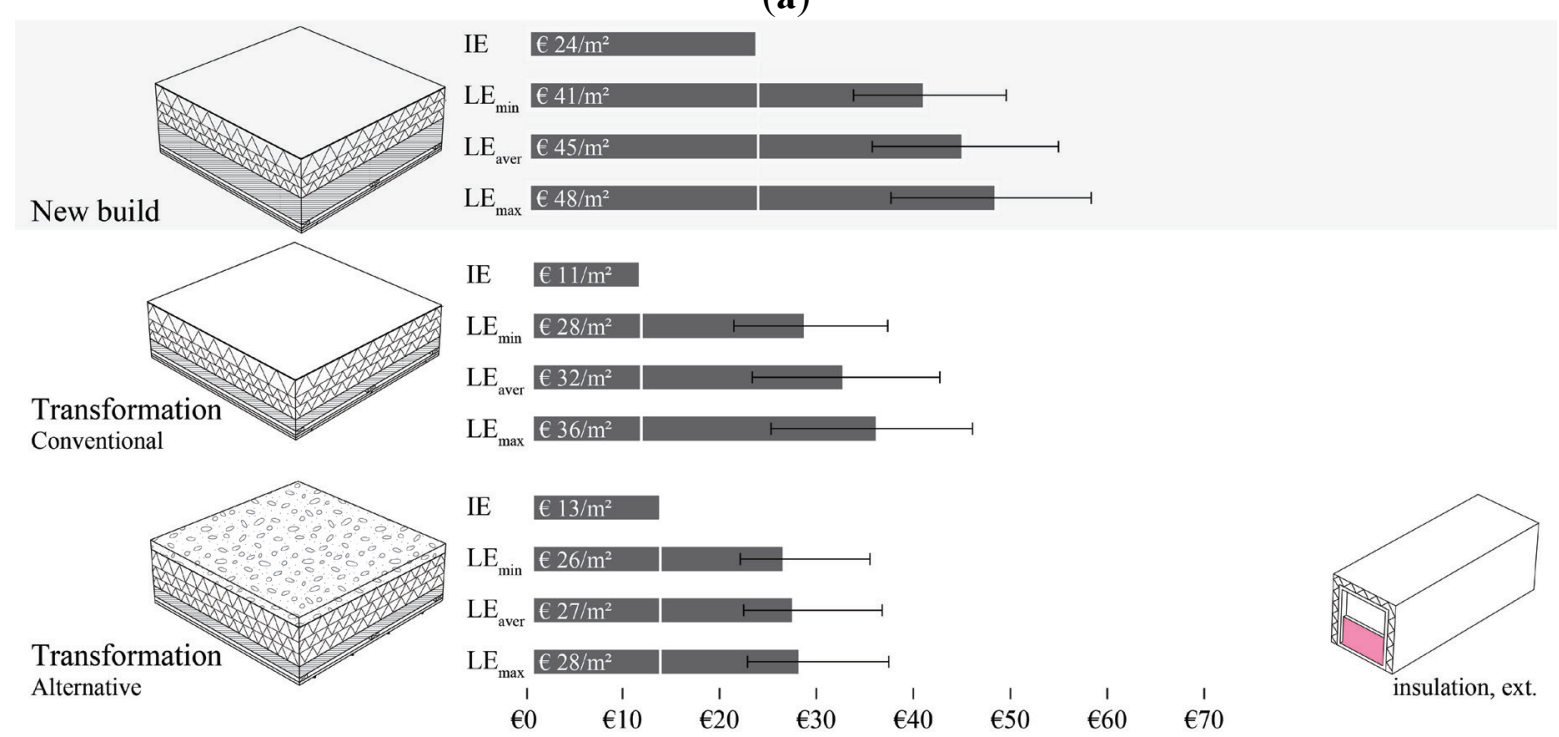

(b)

Figure 7. Based on the outcomes of life cycle assessments of the roof, with (a) internal or (b) external insulation, the conclusions are similar for both cases again: transformation with demountable elements has the lowest life cycle impact. With IE as initial environmental impact, LEmin as life cycle impact with no refurbishments, LEaver as life cycle impact with an average number of refurbishments, LE $\max$ as life cycle impact with a maximum number of refurbishments during 60 years, the error bars represent the results of the sensitivity analysis on a variable lifespan of the building (from 30 to 79 years). 


\subsection{Evaluation at building level}

The building elements were used to design a preliminary possible transformation of some of the modules to an information hub. With the aid of a Building Information Model (BIM) we calculated how much material is needed to renovate these modules according to contemporary standards and requirements. The new design for a renovated module cluster that is being evaluated has a useful floor surface of $433 \mathrm{~m}^{2}$ and $49 \mathrm{~m}^{2}$ covered terraces. The useful floor surface is reduced with $30 \%$ compared to the existing useful floor area of $692 \mathrm{~m}^{2}$ to create new voids that provide public spaces with pleasant user comfort levels. The initial environmental impact of this transformation was calculated for each strategy. The stripping of the modules, the addition of new materials and the impacts of the building process are included in the initial environmental impact, and the discounted life-cycle impact was calculated as well.

Figure 8 indicates that the initial and life cycle impact of a new construction is significantly higher compared to the renovated cluster. The impact of demolishing the structure and its foundations and rebuilding a new structure has a large influence on the overall results. There are no large differences between placing the insulation layer on the inside or on the outside. However, it can generally be stated that the internal insulation scores better, because less material is needed during the transformation. The "demolition" strategy of course has the lowest impact, but the results of this strategy cannot be compared to the other strategies as the functional unit is different.

Figure 8 illustrates that if it is plausible that no future refurbishments will happen, it is better to implement a conventional detailing and to place the insulation layer on the inside of the construction. With the number of forthcoming refurbishments equal to or higher than the average, it is more interesting to detail the buildings in an alternative way. Because of the commercial and temporary character of the potential functions of the student residences we can imagine that there will be several refurbishments in the future and thus an alternative detailing will ensure a lower impact in the long run.

These results can be further optimised by, e.g., combining conventional with alternative elements, as accomplished in [42]. From the previous paragraph we know that the proposed conventional external wall scores better than the alternative version in all cases. The high impact of the alternative external wall has a great influence on the overall impact of a building, a conclusion also reached in [19]. Both the initial and the life cycle impact can be decreased by combining conventional external wall elements with alternative interior walls, floors and roofs. Another way of optimising a low life cycle impact is by redesigning the alternative external wall. If we use other boards than plywood as a finishing — such as gypsum boards - the impacts can be reduced too.

In this evaluation, the possibility of entirely transforming the external wall — such as a change in size of the transparent surface-was not considered. If we include this sort of refurbishment in the evaluation, we can imagine that building the external wall in an alternative way may possibly even lead to larger environmental gains.

In order to value the significance of the different life cycle stages of the student residences, a subdivision of the life cycle impact in life cycle stages was made in Figure 9 for the strategy "transformation insulated internally". The results of Figure 9 point out that the contribution of the impacts during the building process and transportation is minor. Previous studies confirm the negligible impact of those life cycle stages $[19,43]$ as well as the relatively low impact of the 
demolition stage $[19,44]$. The stripping of the modules and the maintenance and repair generate a rather small impact from $€ 2,600$ to $€ 5,400$ compared to the impact of manufacturing of $€ 23,900$. The replacements during the total life cycle have a similar impact of $€ 16,800$. The impact of future refurbishments must not be underestimated either. Especially if more public and more commercial functions are housed in the modules, there will probably be more future refurbishments planned, such as a modified plan layout. It also becomes clear that the energy consumption still has a large impact on the total impact, which is confirmed in other studies, such as [43].

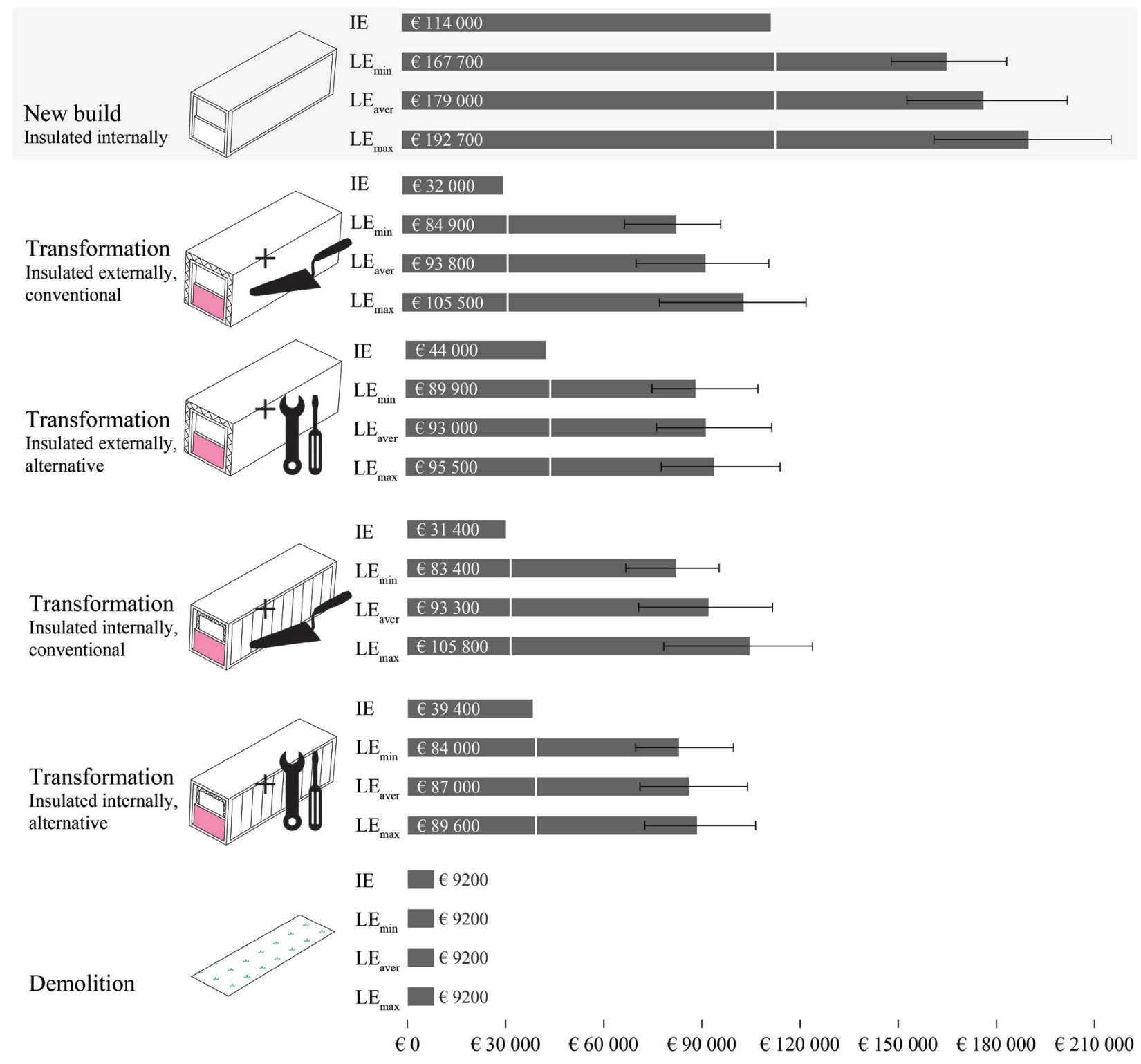

Figure 8. The outcomes of the life cycle assessments for the cluster of modules (with a floor area of $433 \mathrm{~m}^{2}$ ) show that a transformation can have a lower impact compared to new construction and that a demountable detailing for all elements is only useful if the refurbishment frequency is average or higher. With IE as initial environmental impact, $\mathrm{LE}_{\min }$ as life cycle impact with no refurbishments, LEaver as life cycle impact with an average number of refurbishments, $\mathrm{LE}_{\max }$ as life cycle impact with a maximum number of refurbishments during 60 years, the error bars represent the results of the sensitivity analysis on a variable lifespan of the building (from 30 to 79 years). 


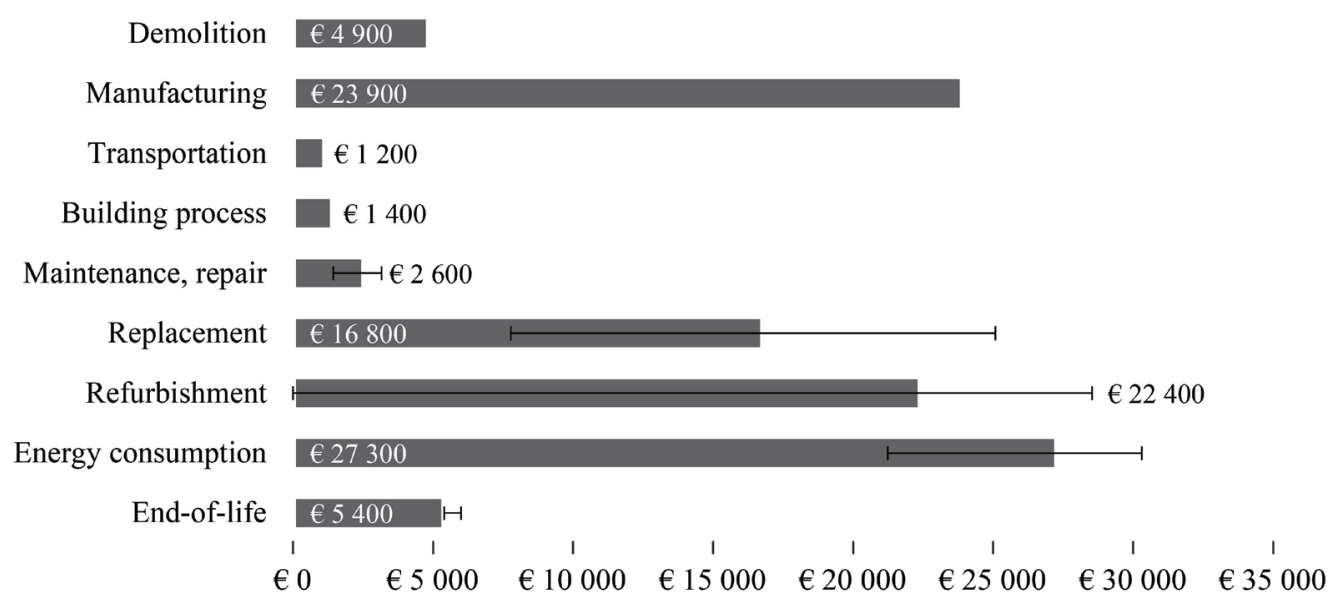

Figure 9. The analysis of the environmental impacts of the different life cycle stage of the transformation strategy with internal insulation of a cluster of modules (with a floor area of $433 \mathrm{~m}^{2}$ ) indicates the life cycle stages with the most significant impact. The error bars represent the results of the sensitivity analysis on a variable lifespan of the building (from 30 to 79 years).

\section{Discussion}

It is important to interpret the results of this study in a broader context. For instance, the results rely on process analysis, using physical quantities of materials and energy for quantifying environmental impacts. This technique neglects processes of inputs at a certain level of the supply chain and does not take into account inputs of related supply chains. For example, the impact of advertising in the built environment is neglected. Those neglected processes are known as truncation errors [45]. Process analyses significantly underestimate the impact of additional materials $[5,46]$, which can alter the order of magnitude of the different life cycle stages in this study. An input-output analysis is systematically more complete for a nation or region by taking all financial transactions into account, converting them into energy flows and consequently into environmental impacts. Nevertheless, process analysis is considered to be more accurate or relevant in a specific context [47]. With an input-output analysis, the environmental impact can be determined relatively quickly, but "aggregation errors" may occur because all products of a sector will have equal energy intensities. A hybrid input-output method can result in a more complete overview of all environmental impacts of a building element. It combines process analysis and input-output analysis without having the drawbacks of both analyses since it uses process data and fills the gaps with input-output data. At the moment there is no reliable public available hybrid database for Belgian construction materials. The most complete database that currently exists is available for the Australian context [48], but is not suitable for the Belgian context since Belgium applies other manufacturing processes and is characterised by a different economic structure, a different electricity mix, etc. [49]. Process-based and input-output-based data sets should be combined, but are currently not harmonised [50]. For our goal, the evaluation and comparison of different design strategies, the use of process data is acceptable as all building materials have a similar truncation error.

Another restriction of the evaluation results is related to the calculated energy consumption due to heating. Future studies should explore in detail the total energy consumption as the energy consumption of commercial buildings can be much higher than, e.g., residential buildings [51]. In addition, the energy 
consumption due to "other uses", such as lighting, electric appliances and domestic hot water, was not included. Indeed, Blengini and Di Carlo proved that when the insulation layer has a high thermal performance, the impact of those other uses may eventually dominate the use phase [43]. Other studies $[2,13]$ considering user transport energy demand reveal the importance of the impact of transport requirements. However, because all strategies are related to the same case in this paper, the transport requirements would be similar for all strategies. This remark is valid for impacts at the urban scale as well.

Sensitivity analysis on a variable lifespan of the building showed that the findings are similar for a longer or a shorter selected lifespan. The differences between the life cycle assessment results of the design strategies become smaller when the remaining lifespan of the student residences decreases. Besides, additional sensitive analyses of key parameters like the discount and inflation rates and the technical service life of the used building materials are also required. Studies [4,30] show that this could refine our results. These analyses must therefore be further executed in future research work.

An additional constraint of our study is the conversion of environmental impacts to monetary units, which is in fact an endpoint method (cf. 0.4). This process is widely used in practice [52] but is rather controversial in LCA practice, because it can be seen as a subjective process. Another set of weighting factors could result in different findings based on the same indicators. Therefore Figure 10 presents the original results of two environmental categories: global warming potential and depletion of non-fossil resources. For both categories, the alternative design strategy (with internal insulation) generates the lowest environmental impact for both the initial and life cycle impact assessment. These results-slightly differing from previous results - can be explained by a higher amount of wood in the alternative design strategy, which has a negative global warming potential due to the captureof $\mathrm{CO}_{2}$ during growth of the trees. A similar conclusion was found in [7]. Consequently, the results of all indicators would give a more complete overview, but carry a hidden uncertainty for decision-making [34].

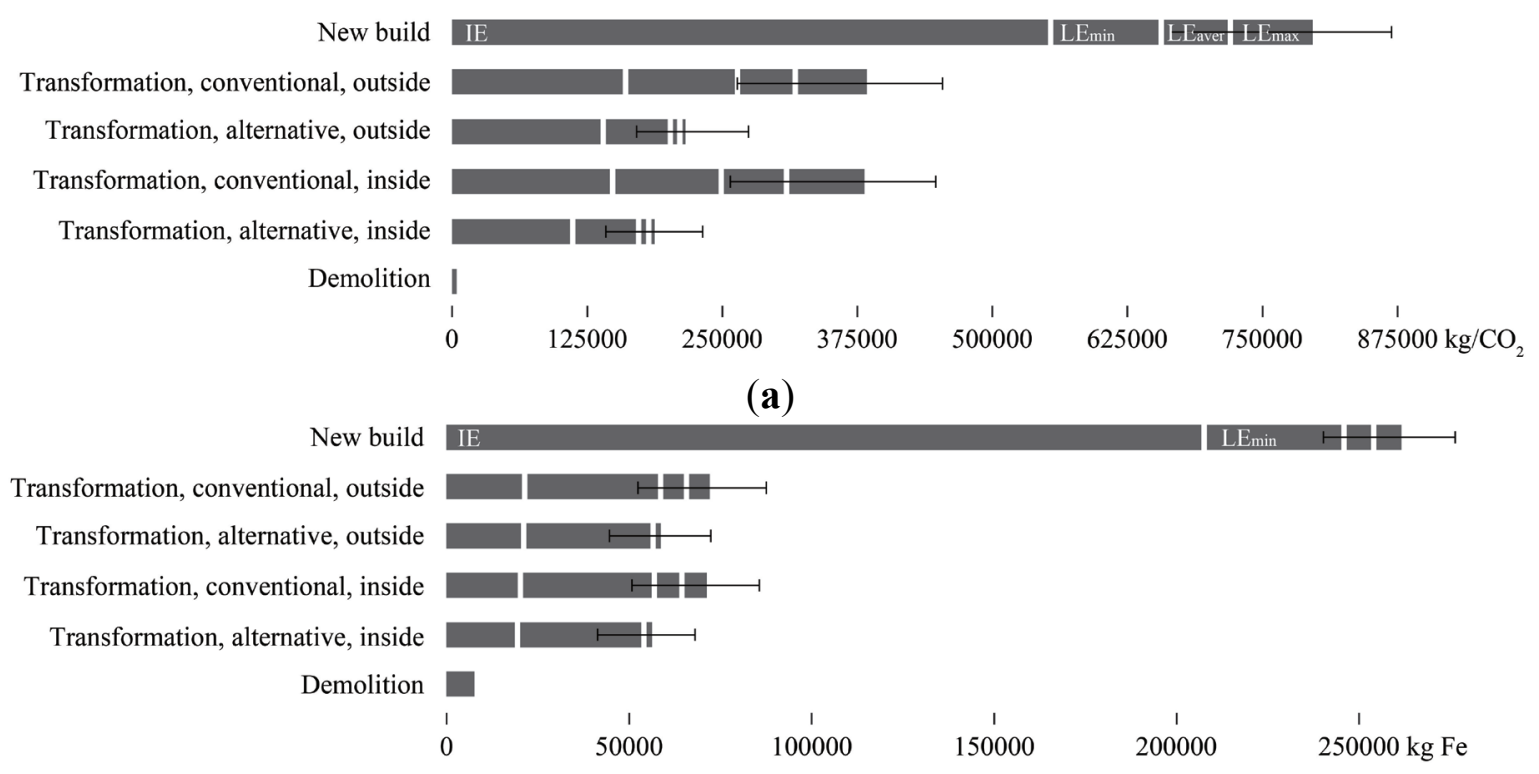

(b)

Figure 10. When focusing on the results of the indicators global warming potential $\left(\mathrm{kg} / \mathrm{CO}_{2}\right)(\mathbf{a})$ and depletion of non-fossil resources (b), it can be concluded that the alternative design strategies have the lowest environmental impact. The error bars represent the results of the sensitivity analysis on a variable lifespan of the building (from 30 to 79 years). 


\section{Conclusions}

This paper indicates that besides the use phase, other life cycle stages may have a significant impact on the total environmental impact of a building. The results showed that future refurbishments must not be neglected since their impact can be comparable to the impact of replacements and the impact of energy consumption in relation to heating. Consequently, the importance of life cycle assessment of buildings and alternative design options was clarified during this study.

Previous studies, such as $[2,9,18]$, applied LCA as a decision-making tool to compare a limited number of structural or insulation materials, but this study clarifies that materials of other layers, such as the finishing layer, can have a large influence on the total environmental impact of a construction assembly as well, which is confirmed in [4].

The environmental life cycle assessments revealed that the reuse and transformation of the student residences have a significantly lower impact than demolishing and rebuilding the modules in the same typology. The impacts of demolishing the structure and its foundations and of rebuilding a new structure influence the overall results to such an extent that the gain remains remarkable in the long term. Nevertheless, new buildings have a longer remaining lifespan compared to transformed student residences - in theory, more than 40 years. This ultimate benefit was not included in the study to guarantee the comparison of equivalent functional units.

It can be generally stated that placing the insulation on the inside of the structure generates a lower impact, since less material is needed during the transformation, but results in a lower useful floor area. An alternative detailing, supporting evolving needs, can provide an additional benefit in the long term if the refurbishment frequency is average or higher. This could be further optimised by, for example, combining conventional with alternative elements. By combining conventional external wall elements with alternative interior walls, floors and roofs the initial impact and the life cycle impact can be decreased when less refurbishments occur. Another optimisation method is designing other demountable variants of the alternative external wall solution.

To summarise, we recommend a more frequent use of the described evaluation methodology in practice when (re)designing buildings in order to get a global picture of environmental impacts of several design options, instead of focusing on merely one life stage usually the initial construction stage. By comparing the life cycle assessment of multiple strategies, it is possible to make decisions without disregarding long-term impacts. Therefore life cycle assessment should be used more frequently as a decision-making tool for designing a sustainable transformation.

\section{Acknowledgments}

This research is funded by IWT, the Agency for Innovation by Science and Technology in Flanders and by the VUB Task Group XY. This assessment was part of a larger research project that has been commissioned by the university's administration. In addition to environmental life cycle assessment it also includes literature reviews, architectural explorations and a life cycle costing assessment. This holistic approach helps put in perspective the outcomes of environmental life cycle assessment and makes it possible to estimate the feasibility of different proposed strategies. The financial counterpart of this paper was published as a conference paper [53]. 


\section{Author Contributions}

Mieke Vandenbroucke and Waldo Galle conceived and designed the simulations; Mieke Vandenbroucke performed and analysed the data; Mieke Vandenbroucke, Waldo Galle, Niels De Temmerman, Wim Debacker and Anne Paduart wrote the paper.

\section{Conflicts of Interest}

The authors declare no conflict of interest.

\section{References}

1. Sodagar, B. Sustainability potentials of housing refurbishment. Buildings 2013, 3, 278-299.

2. Stephan, A.; Crawford, R.H.; de Myttenaere, K. A comprehensive assessment of the life cycle energy demand of passive houses. Appl. Energy 2013, 112, 3-34.

3. Trachte, S.; Massart, C. Reducing the environmental impact of new dwellings: Analyse of the balance between heating energy savings and environmental assessment of the building materials. Archit. Sustain. Dev. 2011, 2, 217-222.

4. Paduart, A. Re-design for Change: A 4 Dimensional Renovation Approach towards a Dynamic and Sustainable Building Stock. Ph.D. Thesis, Vrije Universiteit Brussel, Brussels, Belgium, 2012.

5. Crawford, R.H. Life Cycle Assessment in the Built Environment; Spon Press: London, UK, 2011.

6. Ciambrone, D. Environmental Life Cycle Analysis; Boca Raton: New York, NY, USA, 1997.

7. Verbeeck, G.; Hens, H. Life cycle inventory of buildings: A calculation method. Build. Environ. 2010, 45, 1037-1041.

8. Thormark, C. A low energy building in a life cycle-Its embodied energy, energy need for operation and recycling potential. Build. Environ. 2002, 37, 429-435.

9. Gustavsson, L.; Joelsson, A. Life cycle primary energy analysis of residential buildings. Energy Build. 2010, 42, 210-220.

10. Stephan, A.; Crawford, R.H.; de Myttenaere, K. Multi-scale life cycle energy analysis of a low-density suburban neighbourhood in Melbourne, Australia. Build. Environ. 2013, 68, 35-49.

11. Cabeza, L.; Rincón, L.; Vilariño, V.; Pérez, G.; Castell, A. Life cycle assessment (LCA) and life cycle energy analysis (LCEA) of buildings and the building sector: A review. Renew. Sustain. Energy Rev. 2014, 29, 394-416.

12. Ramesh, T.; Prakash, R.; Shukla, K.K. Life cycle energy analysis of buildings: An overview. Energy Build. 2010, 10, 592-600.

13. Stephan, A.; Crawford, R.H.; de Myttenaere, K. Towards a comprehensive life cycle energy analysis framework for residential buildings. Energy Build. 2012, 55, 592-600.

14. Fay, R.; Treloar, G.; Iyer-Raniga, U. Life-cycle energy analysis of buildings: A case study. Build. Res. Inf. 2000, 28, 31-41.

15. Dahlstrøm, O.; Sørnes, K.; Eriksen, S.T.; Hertwich, E.G. Life cycle assessment of a single-family residence built to either conventional- or passive house standard. Energy Build. 2012, 54, 470-479.

16. Blom, I.; Itard, L.; Meijer, A. Environmental impact of building-related and user-related energy consumption in dwellings. Build. Environ. 2011, 46, 1657-1669. 
17. Debacker, W.; Allacker, K.; Spirinckx, C.; Geerken, T.; De Troyer, F. Identification of environmental and financial cost efficient heating and ventilation services for a typical residential building in Belgium. J. Clean. Prod. 2013, 57, 188-199.

18. Rossi, B.; Marique, A.-F.; Glaumann, M.; Reiter, S. Life-cycle assessment of residential buildings in three different European locations, basic tool. Build. Environ. 2012, 51, 395-401.

19. Dodoo, A.; Gustavsson, L.; Sathre, R. Lifecycle primary energy analysis of low-energy timber building systems for multi-storey residential buildings. Energy Build. 2014, 81, 84-97.

20. Vrebos, H. De Studentenwijk (1971-1973) Van De Vrije Universiteit Brussel te Etterbeek: Industrialisatie Binnen Het Oeuvre van Willy Van Der Meeren (1923-2002). Master's Thesis, Vrije Universiteit Brussel, Brussels, Belgium, 2012. (In Dutch)

21. Sels, G. Ieder zijn huis! De Standaard, 16 May 2012, D8-D9. (In Dutch)

22. Krucker, B. Werk-Serie. Fritz Stucky Architekt und Unternehmer; Gta Verlag: Zürich, Switzerland, 2006.

23. CEN. ISO 14040: Environmental Management-Life Cycle Assessment-Principles and Framework; European Committee for Standardization: Brussels, Belgium, 2006.

24. CEN. ISO 14044: Environmental Management-Life Cycle Assessment-Requirements and Guidelines; European Committee for Standardization: Brussels, Belgium, 2006.

25. SBR. Levensduur van Bouwproducten-Methode voor Referentiewaarden, 1st ed.; SBR: Rotterdam, the Netherlands, 2011; pp. 10-17.

26. Frishknecht, R.; Althaus, H.-J.; Doka, G.; Dones, R.; Heck, T.; Helleweg, S.; Hischier, R.; Jungbluth, N.; Nemecek, T.; Rebitzer, G.; et al. Overview and Methodology; Swiss Centre for Life Cycle Inventories: Duebendorf, Switzerland, 2013.

27. Allacker, K.; Debacker, W.; Delem, L.; De Nocker, L.; De Troyer, F.; Janssen, A.; Peeters, K.; Servaes, R.; Spirinckx, C.; Van Dessel, J. Environmental Profile of Building Elements: Towards an Integrated Environmental Assessment of the Use of Materials in Buildings; OVAM: Mechelen, Belgium, 2013.

28. Kotaji, S.; Schuurmans, A.; Edwards, S. Life-cycle Assessment in Building and Construction: A State-of-the-Art Report; SETAC-Europe: Brussels, Belgium, 2003.

29. Debacker, W.; Allacker, K.; De Troyer, F.; Janssen, A.; Delem, L.; Peeters, K.; De Nocker, L.; Spirinckx, C.; Van Dessel, J. Milieugerelateerde Materiaalprestatie van Gebouwelementen; OVAM: Mechelen, Belgium, 2012.

30. Allacker, K. Sustainable Building: The Development of an Evaluation Method. Ph.D. Thesis, KU Leuven, Leuven, Belgium, 2010

31. CEN. EN 15804: Sustainability of Construction Works-Environmental Product Declaration-Core Rules for the Product Category of Construction Products; European Committee for Standardization: Brussels, Belgium, 2012.

32. De Haes, U.; Finnveden, G.; Goedkoop, M.; Hertwich, E.G.; Hofstetter, P.; Klöpffer, W.; Krewitt, W.; Lindeijer, E. Life Cycle Impact Assessment: Striving towards Best Practice; SETAC Press: Pensacola, FL, USA, 2002.

33. Finnveden, G.; Hauschild, M.Z.; Ekvall, T.; Guinée, J.; Heijungs, R.; Hellweg, S.; Koehler, A.; Pennington, D.; Suh, S. Recent developments in Life Cycle Assessment. J. Environ. Manag. 2009, 91, 1-21. 
34. Lenzen, M. Uncertainty in impact and externality assessments-Implications for decision-making. Int. J. Life Cycle Assess. 2006, 11, 189-199.

35. JRC-IES. ILCD Handbook: International Reference Life Cycle Data System, 1st ed.; European Union: Luxemburg, Luxemburg, 2011.

36. Goedkoop, M.; Heijungs, R.; Huijbregts, M.; De Schryver, A.; Struijs, J.; van Zelm, R. ReCiPe 2008, A Life Cycle Impact Assessment Method Which Comprises Harmonised Category Indicators at the Midpoint and the Endpoint Level, 1st ed.; RVIM: Bilthoven, the Netherlands, 2013.

37. De Brusselse Hoofdstedelijke Regering. Besluit van de Brusselse Hoofdstedelijke Regering tot vaststelling van de eisen op het vlak van de energieprestatie en het binnenklimaat van gebouwen; De Brusselse Hoofdstedelijke Regering: Brussels, Belgium, 2008.

38. BIM. Asbest in uw Woning: Praktische Tips; Leefmilieu Brussel: Brussels, Belgium, 2014.

39. Belgisch Staatsblad. Koninklijk Besluit van 12 Juli 2012 tot Wijziging van Het Koninklijk Besluit van 7 Juli 1994 Tot Vaststelling van de Basisnormen Voor de Preventie van Brand en Ontploffing Waaraan de Nieuwe Gebouwen Moeten Voldoen; Belgisch Staatsblad: Brussels, Belgium, 2012.

40. NBN. NBN S01-401: Akoestiek-Grenswaarden voor de Geluidsniveaus Om Het Gebrek aan Komfort in Gebouwen te Vermijden; Bureau voor Normalisatie: Brussels, Belgium, 1987.

41. Haas, M. NIBE's Basiswerk Milieuclassificaties Bouwproducten: De Leidraad Bij Het Realiseren van Duurzame en Gezonde Woning-En Utiliteitsbouw, 1st ed.; NIBE Research bv: Bussum, the Netherlands, 2012.

42. Paduart, A.; De Temmerman, N.; Trigaux, D.; De Troyer, F.; Debacker, W.; Danschutter, S. Casestudy Ontwerp van Gebouwen in Functie van Aanpasbaarheid: Mahatma Gandhiwijk; OVAM: Mechelen, Belgium, 2013.

43. Blengini, G.A.; Di Carlo, T. The changing role of life cycle phases, subsystems and materials in the LCA of low energy buildings. Energy Build. 2010, 42, 869-880.

44. Winistorfer, P.; Chen, Z.; Lippke, B.; Stevens, N. Energy consumption and greenhouse gas emissions related to the use, maintenance, and disposal of a residential structure. Wood Fiber Sci. 2005, 37, 28-139.

45. Suh, S.; Lenzen, M.; Treloar, G.J.; Hondo, H.; Horvath, A.; Huppes, G.; Jolliet, O.; Klann, U.; Krewitt, W.; Moriguchi, Y.; et al. System boundary selection in life-cycle inventories using hybrid approaches. Environ. Sci. Technol. 2004, 38, 657-664.

46. Crawford, R.H. Validation of a hybrid life-cycle inventory analysis method. J. Environ. Manag. 2008, 88, 496-506.

47. Treloar, G.J. Environmental assessment using both financial and physical quantities. In Proceedings of the 41st Annual Conference of the Architectural Science Association ANZAScA, Victoria, Australia, 14-16 November 2007.

48. Treloar, G.J.; Crawford, R.H. Database of Embodied Energy and Water Values for Materials; The University of Melbourne: Melbourne, Australia, 2010.

49. Stephan, A.; Stephan, L. Reducing the total life cycle energy demand of recent residential buildings in Lebanon. Energy 2014, 74, 618-637.

50. Majeau-Bettez, G.; Strømman, A.H.; Hertwich, E.G. Evaluation of process- and input-output-based life cycle inventory data with regard to truncation and aggregation issues. Environ. Sci. Technol. 2011, 45, 10170-10177. 
51. Sharma, A.; Saxena, A.; Sethi, M.; Shree, V.; Varun. Life cycle assessment of buildings: A review. Renew. Sustain. Energy Rev. 2011, 15, 871-875.

52. Hansen, O.J. Status of Life Cycle Assessment (LCA) activities in the Nordic region. Int. J. Life Cycle Assess. 1999, 44, 315-320.

53. Galle, W.; Vandenbroucke, M.; De Temmerman, N. Life Cycle Costing as an Early Stage Feasibility Analysis: The Adaptable Transformation Of Willy Van Der Meeren's Student Residences. Procedia Econ. Financ. 2015, 21, 14-22.

(C) 2015 by the authors; licensee MDPI, Basel, Switzerland. This article is an open access article distributed under the terms and conditions of the Creative Commons Attribution license (http://creativecommons.org/licenses/by/4.0/). 